\title{
Reclassification of Staphylococcus pulvereri Zakrzewska-Czerwińska et al. 1995 as a later synonym of Staphylococcus vitulinus Webster et al. 1994
}

\author{
Pavel Švec, ${ }^{1}$ Marc Vancanneyt, ${ }^{2}$ Ivo Sedláček, ${ }^{1}$ Katrien Engelbeen, ${ }^{2}$ \\ Vlastimil Štětina, ${ }^{1}$ Jean Swings ${ }^{2}$ and Petr Petrášs ${ }^{3}$ \\ ${ }^{1}$ Czech Collection of Microorganisms, Faculty of Science, Masaryk University, Tvrdého 14, \\ 602 00, Brno, Czech Republic \\ ${ }^{2}$ BCCM/LMG Bacteria Collection, Ghent University, K. L. Ledeganckstraat 35, B-9000 Gent, \\ Belgium \\ ${ }^{3}$ Reference Laboratory for Staphylococci, National Institute of Public Health, Šrobárova 48, \\ 100 42, Praha 10, Czech Republic
}

Correspondence

Pavel Švec

mpavel@sci.muni.cz
Staphylococcus vitulinus and Staphylococcus pulvereri represent novobiocin-resistant and oxidase-positive staphylococci, together with Staphylococcus fleurettii, Staphylococcus sciuri and Staphylococcus lentus. Both species have been isolated from human and animal specimens. S. vitulinus was described by Webster et al. (1994) as Staphylococcus vitulus; the name was later corrected to S. vitulinus by Trüper \& De'Clari (1998). The species was clearly separated by biotyping, ribotyping and DNA-DNA hybridization from S. sciuri and S. lentus. Zakrzewska-Czerwińska et al. (1995) described S. pulvereri; all strains representing this taxon were clearly separated from the novobiocin-resistant oxidase-positive staphylococci $S$. sciuri and S. lentus by molecular as well as chemotaxonomic methods, but unfortunately this study did not include representatives of S. vitulinus. Another member of this group, S. fleurettii, was described by Vernozy-Rozand et al. (2000), who included all the above-mentioned taxa in their study except S. pulvereri. Petrás (1998) opened the question of the synonymy of $S$. vitulinus and $S$. pulvereri on the basis of biochemical testing of S. pulvereri strains NT $215^{\mathrm{T}}$ $\left(=\right.$ CCM $\left.4481^{\mathrm{T}}\right)$, NT 322 and ATCC 51699 and S. vitulinus $\mathrm{SVI}^{\mathrm{T}}\left(=\mathrm{CCM} 4511^{\mathrm{T}}\right)$. He obtained aberrant results in 12

Published online ahead of print on 15 June 2004 as DOI 10.1099/ ijs.0.63080-0. biochemical tests for one or more strains tested compared with the original descriptions. The very close phylogenetic relationship of these two staphylococci based on 16S rRNA gene sequence analysis was shown by Takahashi et al. (1999). Similarly, Poyart et al. (2001) found $99 \cdot 5 \%$ identity of the $\operatorname{sod} A_{\text {int }}$ gene sequences of $S$. vitulinus and $S$. pulvereri representatives. Chesneau et al. (2000) found either similar or identical ribotypes of these two species. Recently, Kwok \& Chow (2003) confirmed the high 16S rRNA gene sequence similarity (99\%) and showed $98 \%$ partial $h s p 60$ gene sequence similarity. Although all of these studies indicated the synonymy of these two species, their taxonomic status has not been clearly revised and clarified.

Bacterial reference strains were obtained from the Czech Collection of Microorganisms (CCM) and from the American Type Culture Collection (ATCC). The Reference Laboratory for Staphylococci, National Institute of Public Health (Prague, Czech Republic) provided seven novel S. pulvereri-/S. vitulinus-like isolates from human clinical origin: strain 98/147 from gastric contents of a newborn, strain 98/779 from an abscess, strain 01/896 from a skin smear during mycosis, strain $02 / 219$ from pectoral puncture fluid and strains $01 / 317,95 / 597(=$ CCM 4512) and 02/418 ( = CCM 7101) from urine.

Biotyping was performed by API STAPH and ID 32 STAPH 


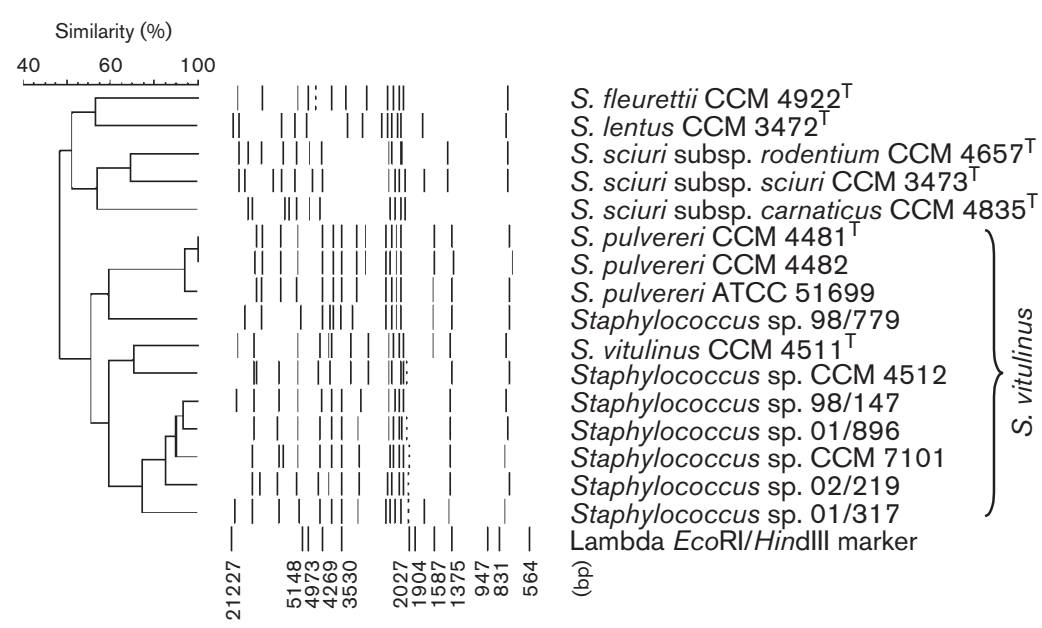

Fig. 1. Dendrogram based on cluster analysis of ribotype patterns (obtained with EcoRI) of $S$. vitulinus, $S$. pulvereri and related oxidase-positive taxa $S$. fleurettii, S. lentus and S. sciuri.
(bioMérieux) as well as by conventional tests as described by Mannerová et al. (2003). Biochemical test results assigned the novel isolates to the $S$. vitulinus/S. pulvereri species group, but could not assign them to one of the two species due to different and variable reactions in several tests when comparing with both original species descriptions.

Ribotyping with EcoRI and a probe complementary to the $16 \mathrm{~S}$ and 23S rRNA of Escherichia coli as well as statistical analysis and dendrogram construction were done as described by Švec et al. (2001). Ribotyping grouped all analysed strains, including S. vitulinus and S. pulvereri representative strains obtained from bacterial collections, into a single cluster (Fig. 1). This group was clearly differentiated from the other novobiocin-resistant and oxidase-positive species, S. fleurettii, S. lentus and all three S. sciuri subspecies.

Whole-cell protein profile analysis, including preparation of whole-cell protein extracts from cells grown for $24 \mathrm{~h}$ on nutrient agar (Oxoid CM3) at $37^{\circ} \mathrm{C}$, SDS-PAGE, densitometric analysis and reading of protein profiles, as well as their numerical analysis, were performed in accordance with the procedure described by Pot et al. (1994). Protein profile analysis was performed using GelComparII software (Applied Maths). The similarity between all pairs of traces was expressed by Pearson's product-moment correlation coefficient, converted for convenience to a percentage value. UPGMA clustering was used for the construction of the dendrogram. The level of reproducibility was investigated by the inclusion of duplicate protein extracts of several strains and a mean correlation of 0.93 was obtained. All S. vitulinus and S. pulvereri strains were grouped in one cluster with similarity values ranging from 89 to $98 \%$ (Fig. 2). This cluster was separated from related novobiocinresistant and oxidase-positive staphylococci.

Whole genomic DNAs for DNA-DNA hybridization were extracted from S. vitulinus CCM $4511^{\mathrm{T}}$, S. pulvereri CCM $4481^{\mathrm{T}}$ and CCM 4482 and from clinical isolate CCM 7101 as described before (Mannerová et al., 2003). As described by the latter authors, DNA-DNA hybridization experiments were performed using the microplate method and determination of the DNA base compositions was done using HPLC. Hybridizations were performed at $33^{\circ} \mathrm{C}$ in hybridization mixture $(2 \times$ SSC, $5 \times$ Denhardt solution, $2.5 \%$ dextran sulfate, $50 \%$ formamide, $100 \mu \mathrm{g}$ denatured salmon sperm DNA $\mathrm{ml}^{-1}, 1250 \mathrm{ng}$ biotinylated probe DNA ml ${ }^{-1}$ ). The DNA-DNA relatedness values obtained ranged from 90 to $100 \%$ and confirmed that all four strains represent one species. The DNA G $+\mathrm{C}$ content was $33 \mathrm{~mol} \%$ for all four strains.
Fig. 2. Dendrogram based on SDS-PAGE analysis of $S$. vitulinus, $S$. pulvereri and related novobiocin-resistant and oxidasepositive staphylococci. 
All data presented in this study as well as all results published previously show clearly the synonymy of $S$. vitulinus and $S$. pulvereri. The reclassification of $S$. pulvereri as a later synonym of $S$. vitulinus is therefore proposed in accordance with Rule 24a of the Bacteriological Code (Lapage et al., 1992).

\section{Emended description of Staphylococcus vitulinus Webster et al. 1994}

Biochemical test results obtained in this study were nearly in full agreement with the species description of S. vitulinus, including variable reactions published by Webster et al. (1994). The only differences were found for acidification of mannitol (described as positive for S. vitulinus; we found three negative strains) and ribose (described as variable; all our strains were negative). Contradictory results were obtained for mannose acidification (described as negative for S. vitulinus). All our strains were negative for this test in ID 32 STAPH kit, but all were positive in API STAPH kit, and conventional testing revealed four positive strains. In addition to the species description, all tested strains were positive for glucose acidification and gelatin hydrolysis; negative for acidification of melibiose and methyl $\alpha$-Dglucopyranoside, Tween 80 as well as arginine dihydrolase and DNase production.

Differentiation of S. vitulinus from the other novobiocinresistant and oxidase-positive species, S. lentus, S. sciuri (including all three subspecies) and S. fleurettii, remains unchanged as described by Webster et al. (1994) and Vernozy-Rozand et al. (2000) except for the mannose acidification test, which gives test-kit-dependent results as discussed above. Moreover, a few controversial biochemical test results were noted for the $S$. fleurettii type strain in this study. The type strain of S. fleurettii, CCM $4922^{\mathrm{T}}$, described as turanose- and L-arabinose-positive, was repeatedly turanose- as well as L-arabinose-negative with the ID 32 STAPH kit and in conventional tests; similarly, trehalose acidification, described as positive for this strain, was negative in the ID 32 STAPH kit, positive in the API STAPH kit and delayed-positive (3 days) in the conventional test.

\section{Acknowledgements}

This study was partially supported by the projects of the Grant Agency of the Czech Republic (project numbers 301/02/1505 and 204/02/ D099).

\section{References}

Chesneau, O., Morvan, A., Aubert, S. \& El Sohl, N. (2000). The value of rRNA gene restriction site polymorphism analysis for delineating taxa in the genus Staphylococcus. Int J Syst Evol Microbiol 50, 689-697.

Kwok, A. Y. C. \& Chow, A. W. (2003). Phylogenetic study of Staphylococcus and Macrococcus species based on partial hsp60 gene sequences. Int J Syst Evol Microbiol 53, 87-92.

Lapage, S. P., Sneath, P. H. A., Lessel, E. F., Skerman, V. B. D., Seeliger, H. P. R. \& Clark, W. A. (editors) (1992). International Code of Nomenclature of Bacteria (1990 Revision). Bacteriological Code. Washington, DC: American Society for Microbiology.

Mannerová, S., Pantůček, R., Doškař, J., Švec, P., Snauwaert, C., Vancanneyt, M., Swings, J. \& Sedláček, I. (2003). Macrococcus brunensis sp. nov., Macrococcus hajekii sp. nov. and Macrococcus lamae sp. nov., from skin of llamas. Int J Syst Evol Microbiol 53, 1647-1654.

Petráš, P. (1998). Staphylococcus pulvereri=Staphylococcus vitulus? Int J Syst Bacteriol 48, 617-618.

Pot, B., Vandamme, P. \& Kersters, K. (1994). Analysis of electrophoretic whole-organism protein fingerprints. In Chemical Methods in Prokaryotic Systematics, pp. 493-521. Edited by M. Goodfellow \& A. G. O'Donnell. Chichester: Wiley.

Poyart, C., Quesne, G., Boumaila, C. \& Trieu-Cuot, P. (2001). Rapid and accurate species-level identification of coagulase-negative staphylococci by using the $\operatorname{sod} \mathrm{A}_{\text {int }}$ gene as a target. J Clin Microbiol 39, 4296-4301.

Švec, P., Sedláček, I., Pantůček, R., Devriese, L. A. \& Doškař, J. (2001). Evaluation of ribotyping for characterization and identification of Enterococcus haemoperoxidus and Enterococcus moraviensis strains. FEMS Microbiol Lett 203, 23-27.

Takahashi, T., Satoh, I. \& Kikuchi, N. (1999). Phylogenetic relationships of 38 taxa of the genus Staphylococcus based on 16S rRNA gene sequence analysis. Int J Syst Bacteriol 49, 725-728.

Trüper, H. G. \& De'Clari, L. (1998). Taxonomic note: erratum and correction of further specific epithets formed as substantives (nouns) 'in apposition'. Int J Syst Bacteriol 48, 615.

Vernozy-Rozand, C., Mazuy, C., Meugnier, H., Bes, M., Lasne, Y., Fiedler, F., Etienne, J. \& Freney, J. (2000). Staphylococcus fleurettii sp. nov., isolated from goat's milk cheeses. Int J Syst Bacteriol 50, 1521-1527.

Webster, J. A., Bannerman, T. L., Hubner, R. J., Ballard, D. N., Cole, E. M., Bruce, J. L., Fiedler, F., Schubert, K. \& Kloos, W. E. (1994). Identification of the Staphylococcus sciuri species group with EcoRI fragments containing rRNA sequences and description of Staphylococcus vitulus sp. nov. Int J Syst Bacteriol 44, 454-460.

Zakrzewska-Czerwińska, J., Gaszewska-Mastalarz, A., Lis, B., Gamian, A. \& Mordarski, M. (1995). Staphylococcus pulvereri sp. nov., isolated from human and animal specimens. Int J Syst Bacteriol 45, 169-172. 